\title{
Sixteenth Census of Seabird Populations in the Sanctuaries of the North Shore of the Gulf of St. Lawrence, 2005
}

\author{
JEAN-FranÇOIS RAIL and Richard COTTER \\ Canadian Wildlife Service, P.O. Box 10100, Ste-Foy, Québec G1V 4H5 Canada
}

Rail, Jean-François, and Richard Cotter. 2007. Sixteenth census of seabird populations in the sanctuaries of the North Shore of the Gulf of St. Lawrence, 2005. Canadian Field-Naturalist 121(3): 287-294.

The Migratory Bird Sanctuaries of the North Shore of the Gulf of St. Lawrence are important breeding grounds for many seabird species. The quinquennial censuses of seabirds in these sanctuaries have been carried out for 80 years (since 1925), in order to detect changes in the distribution and population levels of seabirds breeding on the North Shore. Between 19981999 and 2005, the most striking trends observed were the near doubling in numbers of Common Eiders in most sanctuaries, and the strong population growth rate of Razorbill. Unexplainable declines of Common Murre and Atlantic Puffin were observed at some of the larger colonies of these species. The last active colonies of Leach's Storm-Petrel (Corossol Island) and Caspian Tern (Île à la Brume) on the North Shore seem on the verge of disappearing, with zero and three birds observed in 2005, respectively. Seabird populations in the larger, more accessible and disturbed sanctuaries are still markedly smaller than in historical times.

Les refuges d'oiseaux migrateurs de la Côte-Nord du Golfe du Saint-Laurent constituent d'importants sites de nidification pour plusieurs espèces d'oiseaux marins. Des inventaires quinquennaux des oiseaux marins dans ces refuges sont effectués depuis 80 ans (depuis 1925), pour détecter les changements dans la répartition et les niveaux de population des oiseaux marins nichant sur la Côte-Nord. Entre 1998-99 et 2005, les tendances les plus marquantes étaient chez l'Eider à duvet, dont les effectifs ont pratiquement doublé dans la plupart des refuges, et chez le Petit Pingouin, dont les populations ont également connu une croissance rapide. Des déclins énigmatiques chez le Guillemot marmette et le Macareux moine ont été observés à plusieurs des colonies les plus importantes de ces espèces. Les dernières colonies actives d'Océanite cul-blanc (à l'île du Corossol) et de Sterne caspienne (à l'île à la Brume) sur la Côte-Nord semblent sur le point de disparaître, avec respectivement zéro et trois oiseaux observés en 2005. Les populations d'oiseaux marins demeurent à des niveaux bien endeça de ceux rapportés historiquement dans les refuges de grande superficie, davantage accessibles et sujets au dérangement.

Key Words: Seabirds, populations, sanctuaries, Atlantic Puffin, larids, alcids, Gulf of St. Lawrence.

The Migratory Bird Sanctuaries of the North Shore of the Gulf of St. Lawrence not only contribute to seabird conservation by protecting important breeding grounds, but through the quinquennial censuses they serve as monitoring areas to detect changes in the distribution and population levels of 15 species of seabirds (scientific names given in Table 1), which in turn orient future research and management.

Since the creation of the sanctuaries on the North Shore in 1925, seabirds breeding in these sanctuaries have been censused approximately every five years. The results of previous surveys have been consistently published (Lewis 1925, 1931, 1937, 1942; Hewitt 1950; Tener 1951; Lemieux 1956; Moisan 1962; Moisan and Fyfe 1967; Nettleship and Lock 1973; Chapdelaine 1980, 1995; Chapdelaine and Brousseau 1984, 1991; Rail and Chapdelaine 2004). Thus the sixteenth census, conducted in 2005, perpetuated an 80 year-old tradition that constitutes, over time, an invaluable database for the management and conservation of seabird populations in Québec. For some species, a very significant proportion of their total breeding population in the province is found in North Shore Migratory Bird Sanctuaries. Furthermore, many species are represented well enough in these sanctuaries to assume that the observed population trends reflect the demographic changes for the entire North Shore. These censuses of seabird colonies are of even greater importance as for most of our seabirds they are the only means to effectively monitor population trends, because most seabird species are not currently covered by other existing monitoring programs. Ultimately, the integrity of the whole seabird community in the sanctuaries can also be used as a sentinel to track environmental changes and to evaluate the health of the Gulf of St. Lawrence marine ecosystem.

The goals of this article are to update population estimates and trends for seabirds breeding in the ten Migratory Bird Sanctuaries of the North Shore of the Gulf of St. Lawrence, to evaluate the situation of each species, and to identify priority issues for their conservation.

\section{Methods}

We used basically the same survey techniques as in 1998-1999 (see Rail and Chapdelaine 2004). The methodology, described in detail for each species and site in Rail and Chapdelaine (2002), is summarized below for each family of birds.

ANATIDS - On Corossol Island, the average nest density (nests/ha) as calculated from six $60 \mathrm{~m} \times 60 \mathrm{~m}$ (0.36 ha) quadrats, was extrapolated to the entire area 
on the island deemed suitable for Common Eiders (Chapdelaine 1978*). In the Betchouane Bird Sanctuary, we used a system of line-transects of varying length on Innu Island and conducted a systematic nest count elsewhere. In Watshishou and Île à la Brume, we counted all eider nests on the same sample of islands used in previous censuses, which covered $12 \%$ and $27 \%$ of the sanctuaries' land area, respectively, and we then extrapolated the average density over the entire area encompassing all the islands. At the Baie des Loups Sanctuary, a combination of methods was used: average nest density was extrapolated from two quadrats on Île Les Blacklands, from a sample of islands at Îles Factory, and from the closest island at Ille no 4; the remaining islands in the sanctuary were systematically censused. Total nest counts were conducted on most large islands at the Îles aux Perroquets and Îles SainteMarie Sanctuaries, representing $57 \%$ and $96 \%$ of the total land area, respectively; average nest densities were extrapolated to the rest of the sanctuaries. At the Gros Mécatina and Saint-Augustin Sanctuaries we also searched for nests on the largest islands, but for the smaller islands, on which we did not land, we counted from a boat all females that flushed and assumed one nest per female observed.

GAVIIDS - Red-throated Loon nests were systematically counted by walking around the ponds on islands presenting suitable open habitat in each sanctuary. In one instance, instead of landing on the island, we noted the presence of a territorial adult.

HYDROBATIDS - We systematically searched for active burrows where colonies had been found in previous censuses. Traditionally, a burrow was considered active if we detected signs, such as soil freshly excavated and/or oily odour characteristic of petrels, or when we were able to reach an adult inside the burrow. In 2005 we also used in some instances a burrow probe (Peep-A-Roo, Sandpiper Technologies Inc.), which consisted of a 1.0-inch diameter video imager with infrared illumination source, on a 3-meter long flexible cord.

PhALACROCORACIDS - Great and Double-crested Cormorant nests were systematically either from the ground, from a lookout point, or from a boat.

LARIDS - On Corossol Island, we counted the number of nests (Np) and the number of adults (Ni) in subcolonies, then we estimated the number of pairs in sectors where we counted only the number of adults present by using the factor $\mathrm{k}(\mathrm{k}=\mathrm{Np} / \mathrm{Ni})$. In these sectors we applied the observed species ratio (Great Black-backed / Herring Gulls) to the calculated number of nests. All gull nests were counted systematically at the Betchouane Sanctuary, and attributed to Herring and Great Black-backed Gulls afterwards according to the observed proportions of adults of both species. A combination of nest counts, adult counts and species ratios was used elsewhere for gulls and terns, except that results have been combined for Arctic and Common Terns in Table 1. For the Black-legged Kittiwake, we counted apparently occupied nests.

ALCIDS - Adult bird counts were used to estimate Black Guillemot populations in all sanctuaries. When colonies of Common Murres, Razorbills and Atlantic Puffins could be visited with minimal disturbance, we systematically counted the eggs and apparently active burrows. For puffins, we occasionally used the PeepA-Roo burrow probe (described in the Hydrobatids survey method) to determine the real occupancy rate of apparently active burrows. At many colonies, for example, burrows that were inaccessible in cliffs or featuring large numbers of birds (especially murres), we avoided disturbance by counting from a distance all individuals at the colony and on nearby waters, using binoculars or a spotting scope. At Corossol Island and Gros Mécatina Sanctuaries, only bird counts were used, whereas all eggs and active burrows were noted at the Betchouane Sanctuary. Population estimates for the large concentrations of alcids at the Baie des Loups, Îles aux Perroquets and Îles Sainte-Marie Sanctuaries were obtained mostly from adult counts. For Atlantic Puffins nesting in the Baie des Loups Sanctuary, we used the method described above for larids, that is we calculated the factor $\mathrm{k}$ (number of active burrows per individual observed at the colony) for sectors on Île Les Blacklands and Île du Loup and used it to estimate the number of pairs for puffins observed elsewhere. Evenly spaced grids and line transects were used on Île aux Perroquets in the Baie de Brador Sanctuary, in order to (1) delimit the area of both the puffin and Razorbill colonies, (2) evaluate mean nest densities, and (3) extrapolate the calculated density to total colony area (see Nettleship 1973* ; Chapdelaine 1978*). Incubating murres were counted on this same island. Also, in the Baie de Brador Sanctuary, numbers of puffins around L'Île-Verte were counted.

\section{Results}

The number of seabird species breeding in North Shore sanctuaries remained at 14 between 1998-1999 and 2005, with the reappearance of the Caspian Tern (3 adults) at the Île à la Brume Sanctuary, and the apparent disappearance of the Leach's Storm-Petrel. If we exclude results from the Saint-Augustin Sanctuary (not surveyed in 1998-1999), the estimated total number of breeding seabirds censused in 2005 ( $\mathrm{n}=107011$ individuals) was very similar to 1998 1999 estimate $(n=103579$; increase of only 3.3\%). However, some species showed marked population changes (Tables 1 and 2). In particular, Common Eider numbers doubled in nearly every sanctuary. The Razorbill population also increased greatly in most sanctuaries (overall annual growth rate of $+7.3 \%$ ) On the other hand, the population of Common Murres dropped by half between 1998-1999 and 2005 . 


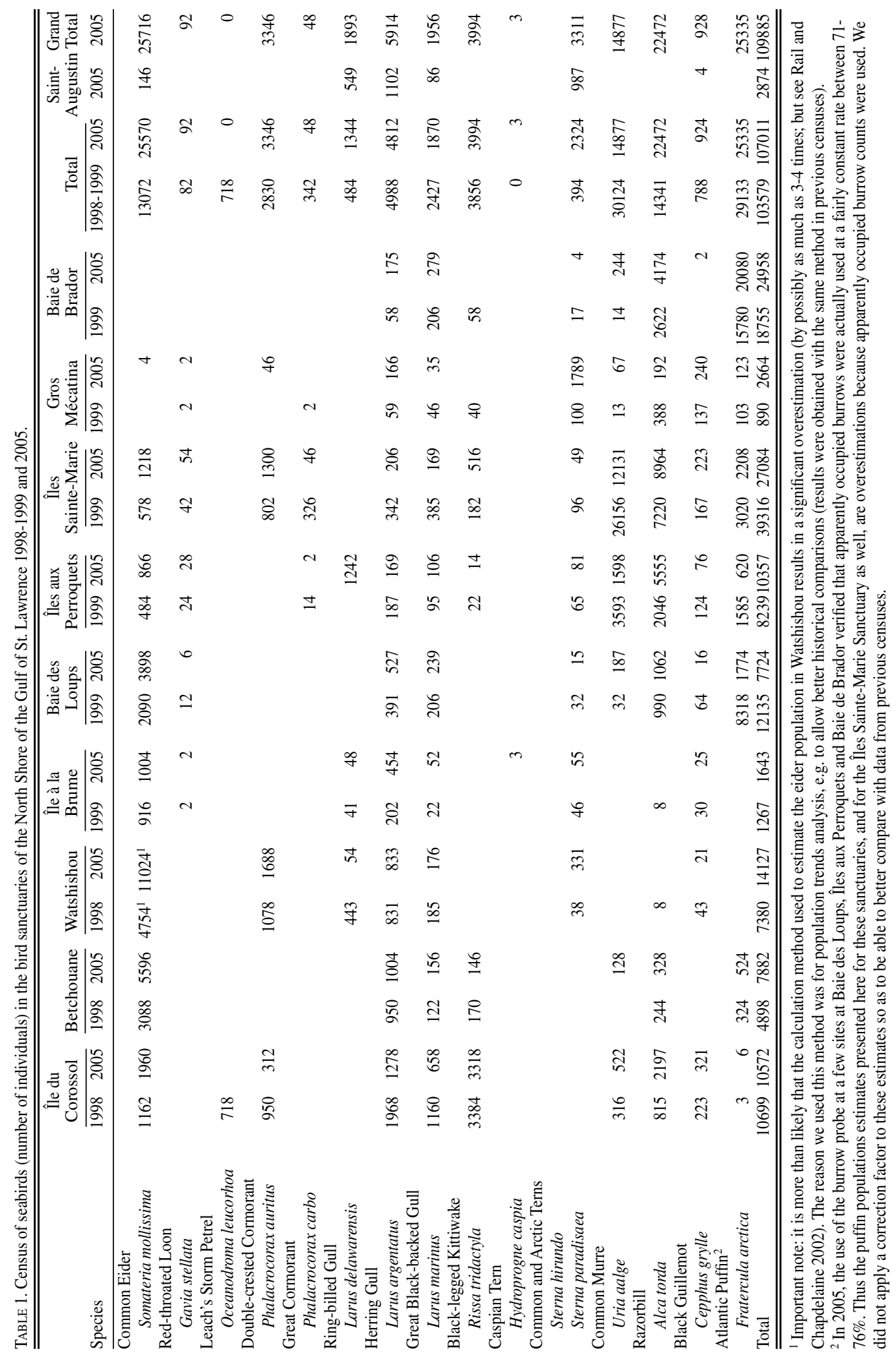


TABLE 2. Changes in the numbers of seabirds in sanctuaries on the North Shore of the Gulf of St Lawrence, Québec, 1993 to 2005.

\begin{tabular}{|c|c|c|c|c|c|}
\hline \multirow[b]{2}{*}{ Species } & \multicolumn{3}{|c|}{ Years of survey rate by period* } & \multicolumn{2}{|c|}{ Compound annual growth } \\
\hline & 1993 & 1998-1999 & 2005 & 1993-1999** & $1999-2005 * *$ \\
\hline Common Eider & 14548 & 13072 & 25570 & $-2.10 \%$ & $9.98 \%$ \\
\hline Red-throated Loon & 66 & 82 & 92 & $3.21 \%$ & $1.92 \%$ \\
\hline Leach's Storm-Petrel & 1840 & 718 & 0 & $-18.38 \%$ & $-100.00 \%$ \\
\hline Double-crested Cormorant & 3472 & 2830 & 3346 & $-3.36 \%$ & $2.82 \%$ \\
\hline Great Cormorant & 78 & 342 & 48 & $24.54 \%$ & $-32.73 \%$ \\
\hline Ring-billed Gull & 104 & 484 & 1344 & $28.43 \%$ & $21.54 \%$ \\
\hline Herring Gull & 4879 & 4988 & 4812 & $0.58 \%$ & $-0.27 \%$ \\
\hline Great Black-backed Gull & 2284 & 2427 & 1870 & $1.27 \%$ & $-3.79 \%$ \\
\hline Black-legged Kittiwake & 6294 & 3856 & 3994 & $-9.98 \%$ & $0.64 \%$ \\
\hline Caspian Tern & 0 & 0 & 3 & - & $100.00 \%$ \\
\hline Common and Arctic Terns & 545 & 394 & 2324 & $-10.99 \%$ & $29.01 \%$ \\
\hline Common Murre & 30829 & 30124 & 14877 & $-0.39 \%$ & $-11.78 \%$ \\
\hline Razorbill & 8389 & 14341 & 22472 & $8.58 \%$ & $7.32 \%$ \\
\hline Black Guillemot & 411 & 788 & 924 & $8.90 \%$ & $2.45 \%$ \\
\hline Atlantic Puffin & 46684 & 29133 & 25335 & $-7.91 \%$ & $-2.34 \%$ \\
\hline
\end{tabular}

$*_{r}=\frac{\log _{\mathrm{e}} \mathrm{N}(\mathrm{t})-\log _{\mathrm{e}} \mathrm{N}(\mathrm{o})}{\mathrm{t}} 100 \%$

** Data from the Saint-Augustin Sanctuary (censused only in 2005) are excluded from this table, as well as data from the Gros Mécatina Sanctuary (not surveyed in 1993) in the 1993-1999 growth rate calculations. Populations in sanctuaries censused in 1998 were extrapolated to 1999 to derive the compound annual growth rate for all North Shore sanctuaries after 6 years.

Although smaller murre colonies grew substantially in size, the bulk of the population, concentrated at Îles Sainte-Marie and Îles aux Perroquets, suffered an unexplainable and severe decline. In other respects, the sharp decreases in Black-legged Kittiwake numbers that were noted in 1993 and 1998-1999 had finally ceased by 2005 at Corossol Island, the largest colony on the North Shore. The 2005 census also showed that Herring Gull populations were quite stable, whereas Great Black-backed Gulls suffered a $23 \%$ overall reduction in numbers compared with 1998-1999. All major Atlantic Puffin colonies showed declines except for the Baie de Brador colony which increased by $27 \%$, and this colony thereby represents the only stronghold of the species in our province.

Corossol Island was visited from 28 May to 30 May. In 1998, the island held the last known colony of Leach's Storm-Petrel on the North Shore (359 active burrows). Unfortunately, no nests were found in 2005. The Double-crested Cormorant colony had 156 nests in 2005, which is only a third of its size in 1998. Conversely, the estimated 980 breeding pairs of Common Eiders in 2005 represent a $69 \%$ increase compared to the 1998 count. We found that the rapid decline of Black-legged Kittiwake numbers, noted during the two preceding censuses, had finally stopped between 1998 and 2005. This species is still the most abundant seabird on the island. Alcids in general showed clear upward trends, in particular the Razorbill population which increased by $170 \%$ during the $1998-2005$ period. Finally, Herring and Great Black-backed Gulls numbers were somewhat reduced in 2005, shrinking back to the levels observed in 1993. The total number of breeding seabirds was similar in 1998 and 2005 at Corossol Island.

On 2 June 2005 the Betchouane Sanctuary was surveyed and Common Eider numbers were found to have had increased by $81 \%$ compared to 1998 . The observed density of nests was impressive as over one-fifth $(21.8 \%)$ of the eiders breeding in all North Shore sanctuaries were concentrated in Betchouane, the smallest sanctuary. Alcids also did well between 1998 and 2005; numbers of Razorbills and Atlantic Puffins had risen significantly, and the 64 Common Murre pairs discovered in 2005 were the first breeding record of this species in the sanctuary. Population levels of gulls and kittiwakes were quite stable between 1998 and 2005. The overall number of breeding seabirds increased by more than $60 \%$.

When we visited the Watshishou Bird Sanctuary on 4 and 5 June 2005, we found the Common Eider population had literally exploded since 1998 (+132\%). The terns had bounced back with an estimated 331 individuals breeding on ten islands, after very few of these birds were seen in $1998(\mathrm{n}=38)$. Three of the four Double-crested Cormorant colonies found in 1998 had grown in numbers in 2005 ( $+56.6 \%$ total increase). Numbers of Herring and Great Black-backed Gulls stayed remarkably stable during the same period. On the other hand, Black Guillemots were less abundant in 2005 than in 1998, and no Razorbills were seen in 2005.Population trends between 1999 and 2005 were 


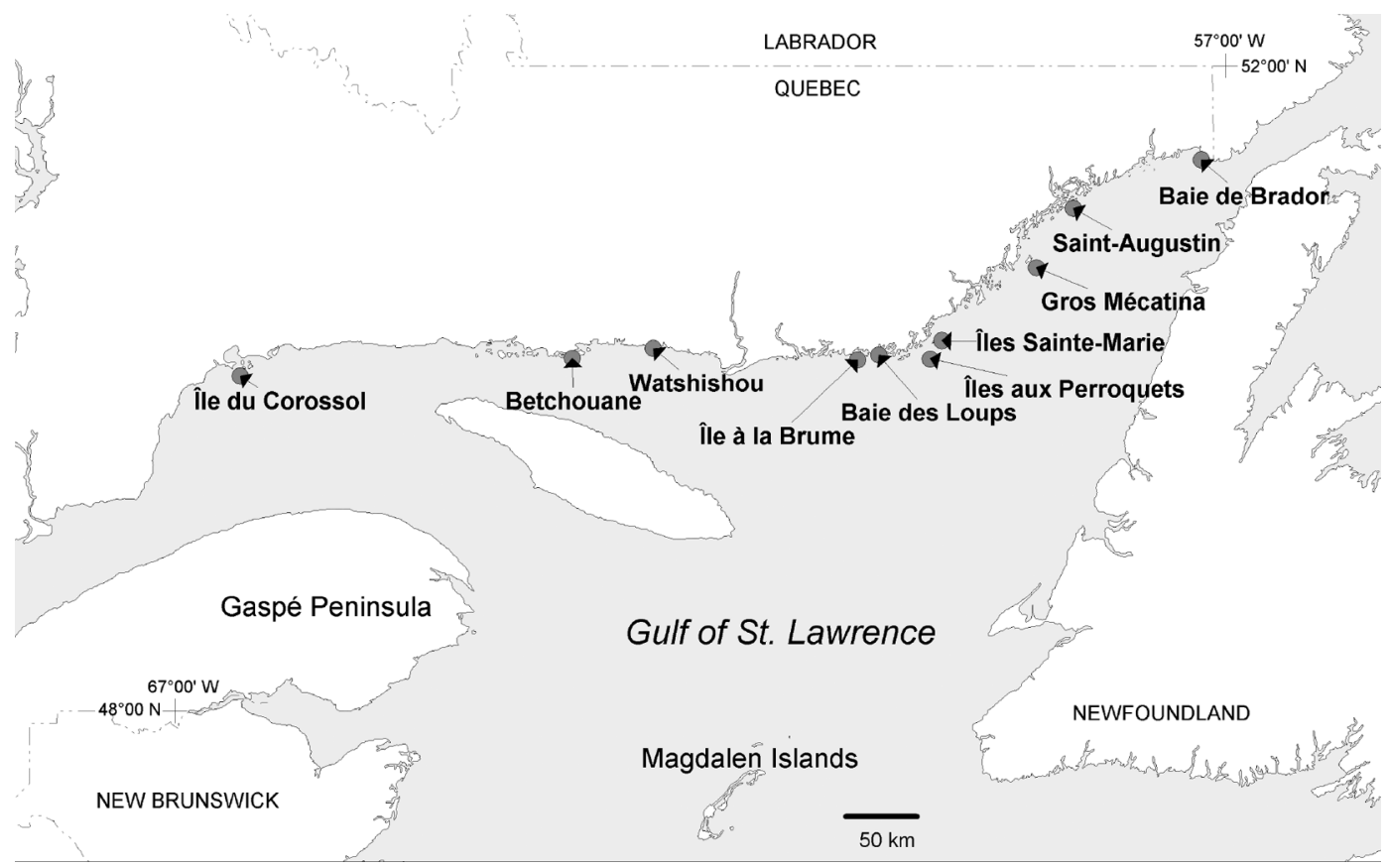

FIGURE 1. Location of the sanctuaries of the North Shore of the Gulf of St. Lawrence.

minor for most species breeding at the Île à la Brume Sanctuary. Even Common Eiders were stable here, whereas spectacular increases were noted for this species in other sanctuaries. The Caspian Tern did a timid comeback with three (presumably) breeding individuals seen in 2005. This species had not been recorded on the two previous quinquennial censuses. Conversely, for the first time since the beginning of the quinquennial censuses in 1925, no Razorbills were seen in this sanctuary in 2005. Only Herring and Great Blackbacked gulls exhibited marked positive trends; their small populations grew more than twofold between 1999 and 2005. The Île à la Brume Sanctuary was visited on 9 and 10 June.

The most striking result for the Baie des Loups Sanctuary (visited on 11, 14 and 19 June) was the extremely low number of Atlantic Puffins observed at Île Les Blacklands, an island which has always been well known for its large puffin colony. Data analysis confirmed the catastrophic puffin decline (-79\%) between 1999 and 2005 in this sanctuary. Since 1960, the Baie des Loups Sanctuary had never held less than $25 \%$ of the total puffin population breeding in North Shore sanctuaries, until this proportion dropped to $7 \%$ in 2005. Black Guillemots also had suffered a sharp decline $(-75 \%)$. Razorbill numbers were similar in 1999 and 2005 , in contrast with the general upward trend observed elsewhere for this species during the same period. On the bright side, the small Common Murre population had become firmly established in the sanc- tuary in 2005 with a near fivefold increase since 1999, and with the appearance of a second colony. Meanwhile, the population of Common Eiders had also risen substantially $(+87 \%)$.

At the Îles aux Perroquets Sanctuary, the total number of breeding alcids stayed relatively stable between 1999 and 2005, but this is because the Razorbills' large population increase $(+172 \%)$ compensated for the declines in Common Murres (-56\%), Atlantic Puffins $(-61 \%)$ and Black Guillemots (-39\%). The Common Eider population grew by $+80 \%$. Meanwhile, Herring and Great Black-backed Gull numbers were nearly stable. Only one of the seven Great Cormorant nests found in 1999 was still active in 2005. Black-legged Kittiwakes seemed also on the verge of disappearing from Îles aux Perroquets, with seven nests left in 2005. The sanctuary was visited on 13 and 22 June.

The Îles Sainte-Marie Sanctuary comprises large islands that hold important concentrations of seabirds, and six days were devoted to their census $(15,17,18$, and 20 to 22 June) in 2005. Alcids showed moderate population trends except for the major drop in Common Murre numbers (-54\%), the most abundant seabird in the sanctuary. There were more than twice as many eider nests as in 1999. Between 1999 and 2005, the Black-legged Kittiwake colony at Île Cliff grew unexpectedly $(+184 \%)$, but other gull populations continued to dwindle in the sanctuary. Such low numbers of breeding Great Black-backed and Herring Gulls had not been seen there since 1950 and 1925, respectively. 
The two species of cormorants showed opposite trends. With an $86 \%$ drop between 1999 and 2005, the size of the Great Cormorant colony in 2005 (23 nests) was the smallest ever recorded since its establishment in the early 1930s, whereas the Double-crested Cormorant colony increased to 650 nests $(+62 \%)$.

The Gros Mécatina Sanctuary was surveyed in two stages: the Îles aux Marmettes and Île Plate were visited on 23 June, whereas Île aux Trois Collines could not be accessed before 7 July. This was only the second quinquennial survey of the Gros Mécatina Sanctuary, which was created in 1996. In 2005, two species had disappeared (Great Cormorant, Black-legged Kittiwake) but were replaced by two others (Double-crested Cormorant, Common Eider). The most significant change was in the tern colony at Île Plate which grew from 50 to nearly 900 pairs between 1999 and 2005. Terns now comprise two-thirds of all breeding seabirds in the sanctuary. Also, the small number of Common Murres observed had increased fivefold. Considering the small size of the sanctuary, the growth $(+75 \%$ between 1999 and 2005) and size ( $n=240$ in 2005) of the Black Guillemot population were impressive.

Our visit to the Saint-Augustin Sanctuary on 25 June 2005 was the first in 17 years. The last time was at the end of the 1980s, when Herring Gull populations were thriving, and just before a widespread decline was observed on the North Shore. The 2005 census confirmed that this trend also occurred at the SaintAugustin Sanctuary, as Herring Gull numbers were down $82 \%$ compared with 1988. The Great Blackbacked Gull population also suffered a $73 \%$ decline during the same period. Alcids, represented by a mere four (4) Black Guillemots in 2005, did not show any signs of recovery. Common Eiders, on the other hand, made a noticeable comeback as they were more than ten times more abundant than in 1988 . However, considering that the Saint-Augustin Sanctuary has the largest land surface area of all North Shore sanctuaries and the fact that between 1935 and 1960 a minimum of five hundred pairs of eiders were recorded in any one census, the estimate of 73 pairs for 2005 looks far from the potential of these islands. The terns, though, were well represented in 2005, with numerous $(n=13)$ colonies and a total population of nearly a thousand birds, the largest ever recorded in this sanctuary.

The largest concentration of breeding Atlantic Puffins in the province of Québec has always been located in the Baie de Brador Sanctuary. Fortunately, our results show a $27 \%$ increase of that colony between 1999 and 2005, in contrast with the declines observed at other major puffin colonies on the North Shore. Baie de Brador now shelters $79 \%$ of all puffins breeding in North Shore sanctuaries. During the same period, the Razorbill population mean annual growth rate was high $(6.9 \%)$ but similar to elsewhere, and numbers of Common Murres went up by an amazing $50 \%$ annual- ly. In other respects, the colony of Black-legged Kittiwakes discovered in 1999 had already disappeared by 2005 . We landed on Île aux Perroquets on 30 June and 1 July, whereas L'Île-Verte could not be reached before 12 August.

\section{Discussion}

Here we present a short analysis of the latest population trend and current status of each species in the North Shore sanctuaries, in order of species in best health (population) to worst. The Common Eider has to come first on the list. Its population has increased dramatically since 1982, and the near-doubling in numbers between 1998-1999 and 2005 represents a very strong population growth rate. The Common Eider is now the most abundant breeding seabird in North Shore sanctuaries. The Razorbill is another species that has been increasing in numbers for more than 20 years in the sanctuaries (as well as everywhere in Eastern North America, Chapdelaine et al. 2001), and there is no indication that this upward trend will slow. Furthermore, many new colony sites were discovered during this period. The size of the Red-throated Loon population was larger than ever in 2005, particularly due to the high numbers reported in the Iles SainteMarie and Îles aux Perroquets sanctuaries. The addition of the latter sanctuary in 1982 helped to protect a significant proportion of this species' small population of only a few hundred individuals spread along the northern coasts of the Gulf of St. Lawrence (DesGranges and Laporte 1979*; Barr et al. 2000; Chapdelaine and Rail 2004). The Black Guillemot has also fared well in the sanctuaries, an exception being at Île à la Brume and Baie des Loups, where breeding numbers have been much higher in the past. Important for the species is the recently created Gros Mécatina Sanctuary (1996); this sanctuary encompasses less than $3 \%$ of the total land surface area of North Shore sanctuaries yet it harboured one-fourth of the Black Guillemot population in 2005. The Double-crested Cormorant, the Common and Arctic Tern, and the Ring-billed Gull were species very well represented in North Shore sanctuaries in 2005. However, the trends observed with these species in the sanctuaries may not be representative for the whole North Shore. In fact, the few colonies of Double-crested Cormorants in the sanctuaries show variable and sometimes contrasting trends. And colonies of terns and Ring-billed Gulls are highly unpredictable, too variable in size and localization (in and out of the sanctuaries from one year to another) to derive meaningful trends.

Herring Gull population trends also tended to vary between sanctuaries, but as a whole the North Shore population has been quite stable since the crash that occurred between 1988 and 1993 (which was associated with the collapse of the cod fishery, see Chapdelaine and Rail 1997). In 2005 the species was well established in all sanctuaries. Great Black-backed 
Gulls were also well represented in every sanctuary, and leaving aside the $43 \%$ decline at Corossol Island, elsewhere the population was stable between 19981999 and 2005. Another species showing relative stability in numbers between the last two quinquennial censuses is the Black-legged Kittiwake. At Corossol Island, the only large colony in North Shore Sanctuaries, the sharp declining trend $(-58 \%)$ observed between 1988 and 1998 had ceased by 2005 . Because of this colony's importance for the species on the North Shore and evidence of very poor reproductive success in 2005 and 2006 (CWS, unpublished data), it is imperative that careful monitoring of the colony occurs in the future. Examination of their diet suggests that when staple food (capelin, sandlance) becomes scarce in their diet, the larger gulls (Herring and Great Black-backed gulls) are more likely to prey on kittiwake chicks.

The Common Murre population had expanded so much between 1972 and the 1990s that it was disappointing to see this recent setback $(51 \%$ decline between 1998-1999 and 2005) which brought the population back to the level observed in 1982. The Common Murre is still the fourth most abundant bird in the sanctuaries, but the underlying factors responsible for the substantial population decline at the largest colonies are not known and will need to be investigated if the species declines in number any further. The Îles Sainte-Marie holds the only wellestablished Great Cormorant colony in North Shore sanctuaries. The number of nests, which once peaked at 339 (in 1955), has been highly variable since 1993 . We can only hope that numbers will bounce back after the lowest number of nests ever recorded there was in 2005, otherwise the species may well disappear from the sanctuaries in the near future. The Atlantic Puffin is not on the verge of vanishing from the sanctuaries; however, its situation is worrying, as the larger colonies located at Baie des Loups, Îles aux Perroquets, Îles Sainte-Marie and Baie de Brador declined by $47 \%$ between 1993 and 2005 . The $79 \%$ decline in six years (1999 to 2005) at Baie des Loups is particularly mysterious, and the colony at the Baie de Brador sanctuary, currently the species' stronghold in the province of Québec, appears vulnerable to disturbance, poaching and bycatch in fishing nets. The fact that three Caspian Terns were observed in 2005 in the Île à la Brume Sanctuary, the only active breeding site in the province, confirms that a small number of individuals of this species continues to frequent the area. We suspect that a few pairs may still breed there sporadically, but it is doubtful that such a tiny population can persist for long if no recovery plan is implemented (but see Shaffer et al. 2004). The first active burrows of Leach's Storm-Petrels were discovered in 1972 in the Baie des Loups Sanctuary. In the censuses that followed, the species was found in three other sanctuaries, with a total of close to 900 burrows in 1982 and 1988. Inexplicably, storm-petrels vanished as fast as they appeared and in 2005 not a single nesting site was found at the last active colony, Île du Corossol. We have no reason to believe that the (unknown) factors responsible for the loss of this species will be reversed in the future.

We identified sanctuaries that seemed in worse shape by comparing the 2005 seabird numbers with historical data in each sanctuary. Some current seabird populations estimates are markedly lower than in historical times. For example, the Île à la Brume Sanctuary once protected a fair number of alcids, including up to 2000 pairs of Common Murres (in 1935). These species declined and never recovered, and in 2005 only a few pairs of Black Guillemot were still breeding in the sanctuary. Alcid populations had also been much larger in the past at the Baie des Loups Sanctuary. At the Saint-Augustin Sanctuary, population levels of Common Eider, Black Guillemot and Red-throated Loon seem far from the potential showed in the 1940s. Moreover, while the Île à la Brume and Saint-Augustin Sanctuaries together represent $40 \%$ of the total land area of the ten North Shore sanctuaries, only $4.1 \%$ of the seabirds were found there. Of course, seabird populations also reflect habitat features, and these two sanctuaries may not have habitats such as cliffs and deep crevices that are most suitable for kittiwakes and murres. But even the Common Eider, which in 2005 was abundant in similar habitat in Watshishou, was rather rare in the Île à la Brume and Saint-Augustin sanctuaries as they harboured only $2.2 \%$ of the total North Shore sanctuaries population. Besides, we saw evidence of eider egg collection in the Saint-Augustin sanctuary in 2005. In these sanctuaries that are comprised of a large number of islands and are easily accessed by boat from nearby villages, the poor density of breeding birds is likely the result of a lack of law enforcement and public awareness the vulnerability of seabird breeding colonies. In addition to improvements in law enforcement and educational programs in local communities, priorities for seabird conservation in North Shore sanctuaries should include population studies to identify the underlying causes of the unexplained declines in Atlantic Puffins and Common Murres and a restoration project for the Caspian Tern colony at Île à la Brume.

\section{Acknowledgments}

Many thanks to everyone who contributed to this census. First, our special thanks go to the Gallienne family for their hospitality on Corossol Island. Fieldwork was carried out with the help of our colleagues Pierre Brousseau, Renaude Bender, Jocelyn Thibault, Raphaël Lavoie and Olivier Meyer, as well as Canadian Wildlife Service game wardens Wilson Evans and Mathieu Nadeau-Monger. Members of Parks Canada in Havre Saint-Pierre, Louis Lalo and many volunteers also gave us a big hand at the Betchouane and Watshishou sanctuaries. Dean and Peggy Martin helped us 
to renew the traditional survey of the Saint-Augustin Sanctuary, which their late father, Canadian Wildlife Service game warden Londus Martin, had patrolled for so many years. We would also like to acknowledge Trish Nash and Tess Cecil-Cockwell from the QuebecLabrador Foundation for their efforts at Baie de Brador and Saint-Augustin sanctuaries, as well as boatmen Lawrence Jones and his son Edward Jones at BlancSablon.

Documents Cited (marked $*$ in text)

Chapdelaine, G. 1978. Onzième inventaire des oiseaux coloniaux des refuges de la côte nord du Golfe Saint-Laurent et révision globale de la fluctuation des populations depuis 1925 jusqu'à 1977. Service canadien de la faune, région du Québec, Environnement Canada, Sainte-Foy. 166 pages.

DesGranges, J.-L., and P. Laporte. 1979. Preliminary considerations on the status of loons (Gaviidae) in Quebec. Unpublished report prepared for the waterfowl working group of the Joint Committee of the James Bay and Northern Quebec Agreement, Canada.

Nettleship, D. N. 1973. Census of seabirds in the sanctuaries of the North Shore of the Gulf of St. Lawrence, summer 1972. Studies on northern seabirds No 20. Canadian Wildlife Service Report, Ottawa. 160 pages.

\section{Literature Cited}

Barr, J. F., C. Eberl, and J. W. McIntyre. 2000. Redthroated Loon (Gavia stellata) in The Birds of North America, No. 513. Edited by A. Poole and F. Gill. The Birds of North America, Inc., Philadelphia, Pennsylvania.

Chapdelaine, G. 1980. Onzième inventaire et analyse des fluctuations des populations d'oiseaux marins dans les refuges de la Côte Nord du Golfe Saint-Laurent. Canadian Field-Naturalist 94: 34-42.

Chapdelaine, G. 1995. Fourteenth census of seabird populations in the sanctuaries of the North Shore of the Gulf of St. Lawrence, 1993. Canadian Field-Naturalist 109: 220226.

Chapdelaine, G., and P. Brousseau. 1984. Douzième inventaire des populations d'oiseaux marins dans les refuges de la Côte-Nord du golfe du Saint-Laurent. Canadian FieldNaturalist 98: 178-183.

Chapdelaine, G., and P. Brousseau. 1991. Thirteenth census of seabird populations in the sanctuaries of the North Shore of the Gulf of St. Lawrence, 1982-1988. Canadian Field-Naturalist 105: 60-66.

Chapdelaine, G., A. W. Diamond, R. Elliot, and G. J. Robertson. 2001. Status and population trends of the Razorbill in eastern North America. Canadian Wildlife Service Occasional Paper 105. Ottawa.
Chapdelaine, G., and J.-F. Rail. 1997. Relationship between cod fishery activities and the population of herring gulls on the North Shore of the Gulf of St Lawrence, Québec, Canada. ICES Journal of Marine Science 54: 708-713.

Chapdelaine, G., and J.-F. Rail. 2004. Québec's Waterbird Conservation Plan. Migratory Bird Division, Canadian Wildlife Service, Québec Region, Environment Canada, Sainte-Foy, Québec. 99 pages.

Hewitt, O. H. 1950. Fifth census of non-passerine birds in the bird sanctuaries of the North Shore of the Gulf of St. Lawrence. Canadian Field-Naturalist 64: 73-76.

Lemieux, L. 1956. Seventh census of nonpasserine birds in the bird sanctuaries of the North Shore of the Gulf of St. Lawrence. Canadian Field-Naturalist 70: 183-185.

Lewis, H. F. 1925. The new bird sanctuaries in the Gulf of St. Lawrence. Canadian Field-Naturalist 39: 177-179.

Lewis, H. F. 1931. Five years' progress in the bird sanctuaries of the North Shore of the Gulf of St. Lawrence. Canadian Field-Naturalist 45: 73-78.

Lewis, H. F. 1937. A decade of progress in the bird sanctuaries of the North Shore of the Gulf of St. Lawrence. Canadian Field-Naturalist 51: 51-55.

Lewis, H. F. 1942. Fourth census of non-passerine birds in the bird sanctuaries of the North Shore of the Gulf of St. Lawrence. Canadian Field-Naturalist 56: 5-8.

Moisan, G. 1962. Eighth census of non-passerine birds in the bird sanctuaries of the North Shore of the Gulf of St. Lawrence. Canadian Field-Naturalist 76: 78-82.

Moisan, G., and R. W. Fyfe. 1967. Ninth census of nonpasserine birds in the sanctuaries of the North Shore of the Gulf of St. Lawrence. Canadian Field-Naturalist 81: 67-70.

Nettleship, D. N., and A. R. Lock. 1973. Tenth census of seabirds in the sanctuaries of the North Shore of the Gulf of St. Lawrence. Canadian Field-Naturalist 87: 395-402.

Rail, J.-F., and G. Chapdelaine. 2002. Quinzième inventaire des oiseaux marins dans les refuges de la Côte-Nord : techniques et résultats détaillés. Série de rapports techniques No. 392. Service canadien de la faune, région du Québec, Environnement Canada, Sainte-Foy. xvi + 307 pages.

Rail, J.-F., and G. Chapdelaine. 2004. Fifteenth census of seabird populations in the sanctuaries of the North Shore of the Gulf of St. Lawrence, 1998-99. Canadian FieldNaturalist 118: 256-263.

Shaffer, F., M. Robert, J.-F. Rail, and V. Létourneau. 2004. La Sterne caspienne (Sterna caspia) au Québec: bilan des connaissances. Série de rapports techniques No. 415. Service canadien de la faune, région du Québec, Environnement Canada, Sainte-Foy, $x+65$ pages.

Tener, J. S. 1951. Sixth census of non-passerine birds in the bird sanctuaries of the North Shore of the Gulf of St. Lawrence. Canadian Field-Naturalist 65: 65-68.

Received 12 January 2007

Accepted 22 May 2008 